\title{
T. S. Eliot: The Renaissance Man of 20th Century; Doppelgänger (the Ghostly Shadow) in J. Alfred Prufrock
}

\author{
Surender K. Rohilla
}

\begin{abstract}
Prufrock', in the guise of T. S. Eliot is indeed a perfect 'Renaissance man of $20^{\text {th }}$ century' caught between the two contradictory forces with the only demarcation that while the renaissance man in Elizabethan age was caught in the pull of medieval and modern forces; whereas, 'Prufrock' is trapped between his own selves. The shadow (doppelgänger) of the split self is always heavier on the mind and character of 'Prufrock'. The central argument in the paper is how the 'doppelgänger' of 'Prufrock' overshadows his real self. The main objective is to find out the causes of a suppressed psyche, an understanding of the process of the building up of 'his' character, and the environment which is instrumental in the making of 'Prufrock'. 'He' is not an ordinary character and as Eliot has said that there is thin line between sanity and insanity, the aim is to bring out the 'abnormal' in 'Prufrock' by tracing the conflicting formative influences on the life of its creator i.e. T. S. Eliot, with the help of the language that he uses in the poem 'Love Song of $J$. Alfred Prufrock', and the way 'he' behaves. The whole exercise seems to start moving in the direction of psychology, religion and theology for a more comprehensive understanding of 'Prufrock'.
\end{abstract}

Index Terms-Doppelgänger, Prufrock, the renaissance man of 20th century, T. S. Eliot.

\section{T. S. ELIOT: A BRIEF INTRODUCTION}

T. S. Eliot is a British as well as an American poet. He can truly be called as "The Renaissance Man of $20^{\text {th }}$ Century". He was more schooled than any other literary figure of his time. His studies in Classical literature cannot be matched by any other writer of his time. Though, it was a modern age, yet we find that Eliot is standing class apart from his generation encompassing all the ages- right from Chaucer till Pound and others. He is a perfect example of "The Renaissance Man of the $20^{\text {th }}$ Century", bringing to fore the conflict in the psyche of the 'modern man' caused because of his trap in the world of old and the new ideas. His erudition hardly leaves any stage of the literary development that it does not bring under its scanner. And similar to the 'Renaissance man', he is trapped in the middle of the old and the new worlds- the medieval and the modern. His conditions often land him into a 'metaphysical' state. He is torn apart at the miserable conditions of the modern man; depicts 'him' in the true light like none before or ever after him, and even finds out the solution to the tragic human existence in his later works such as 'Four Quartets'. He is indeed a true man of his times. Like, he himself vacillates between the two great nations and the conflicting worlds of science, religion and philosophy, his

Manuscript received April 29, 2015; revised August 11, 2015.

S. K. Rohilla is with the Department of English, Motilal Nehru College, University of Delhi, South Campus, New Delhi 110021, India (e-mail: surendrarohilla@yahoo.com). celebrated character 'Prufrock' too vacillates between his 'two selves' entangled between the two opposing and conflicting forces before finally surrendering in favor of his 'Doppelgänger'. It would be improper to discuss 'Prufrock' without a look at the formative influences on the life of T S Eliot.

\section{T. S. ELIOT: FORMATIVE INFLUENCES}

Thomas Streans Eliot was born on 26 September 1888 in St Louis, Missouri. His first ancestor came from East Coker in England and was a Calvinist. Eliot's grandfather William Greenleaf Eliot was a Harvard graduate and a Unitarian minister, who later on moved to St. Louis from Boston. Apart from being a leading philanthropist, he was also a financial genius. Thomas Stearns Eliot was born of Henry Ware Eliot and Charlotte Champe Stearns. He was their seventh child.

His family background played a vital role in the growth of his nerves and cerebral cortex. He later asserted that 'the primary channel of transmission of culture is the family: no man wholly escapes from the kind, or wholly surpasses the degree, of culture which he acquired from his early environment' [1]. The dominant influence during his childhood was that of his grandfather. Although, he (W. G. Eliot) had passed away the year before Eliot was born; however, his influence cannot be overlooked. Eliot's later conservatism too was a product of this influence. His grandfather believed that religion and law are the great conservative influences of society and that all great social changes, to be beneficial, must be slow. Eliot acknowledged that 'the standard of conduct was that which my grandfather had set; our moral judgments, our decisions between duty and self-indulgence, were taken as if, like Mosses he had brought down the tables of law, any deviation from which would be sinful' [2]. By this, he emphasized the law of public service operating in three areas: the Church, the city and the University. The deep interest of the family code upon the sensibility of the child can be glimpsed in the seven-year-old Eliot's conclusion to his brief biography of George Washington: 'And then he died, of course. He was never said to say a lie. He died at Mount Vernon' [3].

Eliot's father did not follow his father's footsteps to become a minister. He instead became a successful businessman despite the fact that he had artistic ambitions. 'When Henry Eliot died in January 1919, the son wrote with regret of his father's youthful possibilities that never came to anything, and with affection and admiration of his old fashioned scholarship, his flute playing, his drawing, and especially his sketches of cats' [4].

Eliot's mother Charlotte too like his father, was a thwarted artist. Her profound, complex and everlasting influence on her 
son cannot be denied or overlooked. Unfortunately, she could not go to university and had to take up school teaching as a career till her marriage, even before she was nineteen. However, she possessed an 'unusual brilliancy' and had a strong sense of social responsibility throughout her life. She dedicated the memoir of her father-in-law 'Lest They Forget' to her children. Her didactic poems are colored with religious sermons. Her temperament towards moral, social and religious order is reflected through the mature poems of her son which show an unparalleled influence of a mother in the formation of the sensibilities of her son. Eliot however, "did not share her faith in the individual's visionary power. Charlotte did not get the recognition she had striven for, and was assiduous in nurturing her son's talent, hoping that he would redeem her sense of failure [5]."

\section{IMPACT OF LANDSCAPE AND CITY LIFE ON ELIOT'S MIND}

As has already been mentioned, Eliot grew up in St, Louis. We find the imprints of St Louis in his literary imagination, sense and sensibility. Quoting Eliot from "The Eliot Family and St Louis" Moody has written, 'as I spent the first sixteen years of my life in St. Louis, it is evident that St Louis affected me more deeply than any other environment has done' [3]. During this time, we find that St Louis was expanding and prosperous. However, at the end of the century, it was plagued by financial and political scandals. So, 'it had become shabby to a degree approaching slumminess', he later reminisced [6]. Hence, the urban imagery depicted in 'Prufrock', is reminiscent of 'St Louis'. This is further supported by no other than the poet himself, 'so it was, that for nine months of the year my scenery was almost exclusive urban, and a good deal of it seedily, drably urban at that. My urban imagery was that of St Louis, upon which that of Paris and London have been superimposed [6]'.

But still, he was, 'very well satisfied with having been born in St Louis', and in fact thought he was fortunate to have been born there rather than in Boston or New York or London' [7]. The knowledge of the prehistoric past was one of the important factors that influenced the course of Eliot's poetry. Missouri and Mississippi had lasting imprint on him. He later reminisced as written by Moody in The Eliot Family and St Louis, 'there is something in having passed one's childhood beside the big river, which is incommunicable to those who have not' [3]. St Louis was adjacent to the Forest Park. Near the center of the Forest park, 'about twelve miles from St Louis could be found a series of prehistoric mounds' [8]. It is conjectured that these mark 'the beginning of Eliot's lifelong preoccupation with the complex relationship of the prehistoric past and the present, and with the problematic concept of the primitive' [5]. It is exclusively reflected in the tension/pull in the character of Prufrock. In contrast to his urban imagery of St Louis, the country landscape influencing him is that of New England cost where his family spent the summers. 'Eliot's favorite author during his childhood and adolescence was Mayne Read, one of the most popular American children's writers of the day who wrote about the Wild West, blood curdling adventures at sea, and 'savages' in remote parts of the globe' [8]. He admits that the only happiness that he derived in life was during his childhood and his second marriage. However, we find that disapproval of some of the authors like Byron, Shelly, Omar Khayyam, Swinburne and Rossetti etc. during his childhood added only to the pleasure of reading them at a later stage.

\section{T. S. ELIOT: THE ROLE OF UNIVERSITY AND SCHOLARS}

Eliot was brought up in a Unitarian environment. Unitarians believe in the oneness of God and reject the doctrine of trinity. Eliot's family occupied a prominent position among the Unitarians and was known by the name of Boston Brahmins. 'They were a paradoxical combination of theological liberalism and social conservatism, possessing an optimistic faith in reform, yet fearing change' [5]. The poet however, revolts against it when he enters Harvard in the year 1906; it is this paradox that forms an integral part of the personality of 'Prufrock'.

Harvard too played a vital role in the growth and personality of the poet. It followed then, an elective system of education. Although, the elective system gave Eliot the opportunity to study a wide range of subjects, Eliot was however, against it owing to its liberalism. It was at Harvard that he came in contact with Irving Babbit and George Santayana. He even took a course in France on the former's advice. Santayana was hostile to Unitarianism and we see that at later stages in life, Eliot too became critical of the sect. Both these great teachers i.e. Babbit and Santayana preached classicism as opposed to romanticism. Babbit was well read in Sanskrit, Pali and Indian Philosophy. He hated the ideas of 'flux' and 'pragmatism', propagated by William James and Bergson. Babbit believed that the classical spirit of the humanist serves as a guide to the same goal as religion, i.e. oneness with the world [9]. However, Eliot later on disagreed with Babbit on the issue, for he could not concede that humanism can serve as an alternative to, or be a substitute for religion [10]. But still, we find a common ground of thought where he plays with Babbit. It is mainly his reflection of mediating between the past and present, and opposition between classicism and romanticism. It is this arrangement and re-arrangement of sensibility in the formative phases of Eliot's career which eventually finds its imprint of dichotomy in the character of 'Prufrock'.

The twentieth century poetry for Eliot was without much substance. So, he turned to nineteenth century poets for inspiration. Thomson's 'The City of Dreadful Night', with its urban settings and a sense of horror had an impressive impact on the setting of 'Prufrock'. Davidson is another poet whose persona in 'Thirty Bob a Week', is a trapped city clerk circumcised by the tentacles of modernity resembling 'Prufrock'; and finally, it is Baudilaire, who taught Eliot the art of depicting the violence and horror of a modern city life. From him, Eliot learnt first 'a precedent for poetical possibilities, never developed by any poet writing in my own language, of the more sordid aspects of modern metropolis, of the possibility of fusion between the sordidly realistic and phantasmagoric, the possibility of the juxtaposition of the matter of fact and the fantastic" [7]. Another notable influence on Eliot was that of Arthur Symons whose 'The Symbolist movement in Literature' had a powerful impact on him, probably teaching him that great cities possess a kind of 'double consciousness.' Above all, it was Dante who exercised 'the most persistent and deepest influence' upon 
Eliot's verse [7]. There are many lines that he borrowed from the writings of Dante and he admits that he borrowed 'in an attempt to arouse in the reader's mind the memory of some Dantesque scene, and thus establish a relationship between the medieval inferno and modern life' [5]. Next among the influences on the psyche of the poet comes 'Paris.' It was here that he came in come contact with the novelist Alain-Fournier with whom he practiced French; and Jean Verdenal-a medical student, to whom he dedicated Prufrock and Other Observations.

The influence of Bergson on Eliot came in direct contrast with the ideas and Action Francaise of Charles Maurras. Maurras and Bergson are contradictory in the sense that Maurras believed in order, reason, hierarchy and discipline whereas Bergson favored intuitive knowledge, impulse and the theories of flux and change. Maurras condemned Rousseau and held him responsible for the malaise of the contemporary problems of the western society. For Maurras, 'there could be no beauty without order, no order without a hierarchy of values, no hierarchy without authority both to define and to endorse it' [11]. However, at this point we find that differences between Babbit and Maurras are increasing and the former had labeled some of the parts of ' $L$ 'Avenir de l'intelligence' as 'romantic antiromanticism'. Babbit even deplored that while defending classicism, Maurras had mesmerized everything right from the romantic art, spreading over to political and religious questions. However, we find Eliot to be a staunch supporter of Maurras and he was taken aback when Action Francaise was condemned by the Vatican in 1926 'for putting religion at the service of a political movement' [5]. But it is also true that Eliot later on justified the action of Pope in the sense that pope was condemning a kind of heresy that advocated only one form of government i.e. monarchial- compatible only with Catholicism. Eliot now started distancing himself from Maurras, and 'in a letter of 13 August 1954, he furiously rebuffed Pound, saying he would tolerate no further insult either to his nationality or to his religion, which included the Jewish religion' as cited in [12].

Eliot enrolled himself as philosophy student at Harvard in 1911, and the period of 1880s up to the First World War is known as 'the golden age of American Philosophy'. The Harvard School of philosophy was known as the best philosophy school in the world. It was influenced by luminaries such as Josiah Royce, Babbit, Santayana and William James. Their main concern at the time was to defend religious beliefs and tradition against the onslaught of Darwinism and new scientific materialism. Hence arose, the need for integration and synthesis of science and religion. In fact, it is religion that gives breathing space to the modern man laid down with the burden of 'demands of life.' Wherever we find the absentia of faith, belief and the deviation from scriptures, we notice that the environment becomes tragic. Individual alienation, solitariness, marital discord, litigation, indiscipline, inefficiency, jealousy and materialism etc. overtake the individual and make him a tragic 'Zero' as he wastes his life in useless pursuits thrust upon him by self-created economic necessities dominated by his 'Doppelgänger'. It is only religion that can save the mankind from the devilish nuisances of modern life which are generated in the name of individualism and democracy. The strong influence of these nuisances cannot be ignored in the case of 'Prufrock'. May be, Eliot's sensibility was through a molding process during these years; however, we do find Eliot a far more mature 'prophet' in the later phase of his poetic development, as 'Four Quartets' is his fabulous gift to the mankind. 'Prufrock' and 'Waste Land' show us the glimpses of the absurdity of modern life whereas his Four Quartets and other religious poems re-write about its salvation.

Another notable influence on Eliot was that of Josiah Royce whom he termed as 'the doyen of American Philosophers'. Josiah talked about an absolute soul that achieves the synthesis between the finite and the infinite. Perhaps, this is what Eliot means when his 'Prufrock' intends 'to squeeze the universe in a ball'. William James' pragmatism and his core idea that 'truth is what works', was also questioned by Eliot for having made man the Centre of all things. However, he was indebted to him for the impact of modern psychical truths on the mysticism and pathological states of mind, which abundantly echo and re-echo in Prufrock. The hallucinatory nature of the persona of 'Prufrock' seems to have a direct impact of James on his personality. However, we find that Eliot clearly demarcated between the morbid states of mind and genuine mysticism in his later poetry. He propagated for the divorce of theology from philosophy. During the writing of Waste Land, he admits how he had almost turned into a Buddhist. Hinduism too had a great influence on the mind of the poet. It is a well-known fact that he was well versed in the classics and was familiar with Bhagwat Gita and Patanjali. His celebrated poem 'Waste Land' is summed up with 'Shantiah'- which is a Sanskrit word propagating 'peace'. He even criticized the misinterpretations of Indian philosophy by western thinkers and admitted that 'to understand Indian Philosophy he would have had to forget how to think and feel as an American or a European, which for practical and sentimental reasons he did not wish to do' [13].

Eliot wrote his dissertation on F. H. Bradley. Bradley believed on the necessity of immediate experience. It is only after the immediate experience that thought and reflection, and ego and self are generated. So, according to him 'absolute' is an all-inclusive system containing all experience. Eliot upheld Bradley's theory of truth and reality and saw separation as a very thin line. He even admitted that difference between sanity and insanity is that of a degree and what seems insane to the ordinary may be an apprehension of a realty which is not understood by the sane. After completing his studies at Harvard, Eliot came to London in 1914. It was here that he had shown 'Prufrock' to Pound on whose suggestion and mediation, it was sent to Monroe- the editor of 'Poetry'.

In June 1915, he married Vivien Haigh-Wood. She was flirtatious, impulsive, hysteric and neurotic, and chronically ill on occasions. Eliot could not devote full time to his writings at this stage. However, she did not let Eliot go the US from England and he is thankful to her for this as he admits, 'had he done so, he felt, he might never have written another line of poetry' [4].

\section{Co-RElation BetweEn the Psyche of 'PRUfrock' AND THE LANGUAGE EMPLOYED BY HIM}

Since the day of its creation, 'Prufrock' has been a complex, 
enigmatic and a fascinating character. The creator of 'Prufrock' was an amalgamation of the ideologies of all the philosophers of his time like William James, Josiah Royce, Irving Babbit, George Santayana, Baudelaire and Maurras etc. It is an irony that instead of becoming a precipitate with all that was available to 'Prufrock', he even fails to come out from within himself.

Every individual is a product of his environment and 'Prufrock' indeed justifies the dilemma of the 'modern man'. We all try to and indeed have to become a part of the surroundings we live in, despite the demands of the modern life. How so ever great an individual might become but he/she has to come back to the social domain. It is at this plane that our success as a human being is defined in totality. This is what our religions teach us and this is perhaps the ultimate goal of life. Even psychologists say that comprehensive growth takes place when after having covered all the stages of development, we start thinking at the level of "Universal Ethical Principles". The desire to grow, the desire to have children and the desire to think according to Universal Ethical Principles is the fundamental need of every individual to bid Good Bye to this world as a 'contented' human being.

'Prufrock' too has such a desire and it is this desire that propels him towards the 'Love Song'. Again, the negation of his proposal though in his own mind only, strengthens our view as negation in psychology is a way of accepting and acknowledging the opposite. However, it is his (in) capability lacking in a strong will that he is never able to realize it. It is not that he is not conscious of his environment but because he is a 'Doppelgänger'. He has two sides of his personality - the one where he knows that Love Song is a sacred exercise and the other where he is conscious that 'it' may not be received well. There is a clash of percepts and concepts in his case resulting in a fragmented psyche and distorted personality. He is a well-bred, well read, knowledgeable modern man who is conscious of his surroundings. However, we notice that because of his (distorted) conception of the world around him, he fails to come out from within and interact with it $\mathrm{He}$ is inarticulate, non-verbal, dichotomous- whenever he is verbal, inert and a nervous wreck lacking in self-confidence. The Bergsonian concept is truly applicable in his case. That "time is a continuum rollum" can aptly be fitted in Prufrock's study. He remembers the past, is conscious of the present but at the same time we find that he is not able to integrate himself with his surroundings, resulting in the hopelessness about future. This is what makes him a different character altogether! His inability to come out of his own self and his (in)ability to confine in the lady of his love or in anyone else except his own self-may be because he is having a different perception of the world of women, make him all the more enigmatic. His persona is 'Dramatic', and his vocalization - a 'monologue'. Hence, he becomes a divided 'self'. There is a clear demarcation between his own worlds- the one that he is in and the other around him which he is (not) in. Both combine in him resulting in a 'Doppelganger' state. There is a tension, a tug of war, a thesis, an anti-thesis resulting in a (non)synthesis; and the attraction and repulsion between the two states of his own 'self' that make 'Prufrock' what he is. The dichotomy of his two selves depicts that he is a 'void'- without any center where integration of his two selves can take place resulting in the achievement of his identity. As a matter of fact, he

\section{becomes an 'Identity Foreclosed' case.}

The tug of war of the opposites is visible right from the epigraph of the poem. Eliot's persona dares to sing only because of the certainty that no one in the world is going to listen to him. He compares himself with the 'Guido da Motefeltro' - a persona in Dante's 'Divine Comedy'. Guido is unwilling to reveal his identity. It is only on the request by Dante and the assured feeling that the listener too is imprisoned like him in the fire of hell, he reveals himself. 'Prufrock' too feels that his listeners too are entrapped like Dante and would not be able to tell anyone because of their confinement and their inability to interact with the outside environment. It is therefore, that he attempts the 'Love Song'. The song after all has to have a title. The title too is fully justified keeping in view the mental state of the persona. First part of the title entitled as "Love Song of" is played against the repulsive name i.e. 'J Alfred Prufrock'. It is indeed a complex situation that a person bearing such an absurd name would ever be able to sing a love song? The ghost of uncertainty, ambiguity and complexity is itself evident in the first line of the poem.

\section{The ARTiculation AND USE OF LANGUAGE IN ' $J$. ALFRED PRUFROCK'}

"Let us go then, you and I"- There are three pronouns. It is really not possible to identify who is the speaker or the listener. Again, after having implored the (supposed) reader to go with him, he forbids him to even ask a question which shows his (in) capacity to articulate- a fact which is further strengthened by the self-assured and confident women's discussion on 'Michelangelo'. We all talk about the global warming, the polluted air in the cities and the release of chlorofluoro carbons in the environment. But still, we long for correcting or ameliorating the adverse conditions. 'Prufrock' talks only about the 'smoke, smog, soot, chimneys and pools that stand in the drains'. Nature moves in a cycle. Every phenomenon is bi-polar. How so ever sinister a night may be, the dawn still comes. 'Prufrock' cannot think of the positives existing in his immediate environment; not that he doesn't know the 'positives' or is unconscious about it but because he lacks the ability to do so. His 'Doppelgänger' is heavier on him. The indeterminacy is crystal clear; and it prepares us for further cover ups of the persona. It is not that 'Prufrock' is alone in this cover-up phenomenon in the annals of English characters. The same happens with Faustus. Faustus, although, is able to overcome the negative perceptions in his mind but 'Prufrock' remains trapped, when he says "No! I am not Price Hamlet, nor was meant to be," In the case of Hamlet which has been termed as "the tragedy of reflection" by Coleridge, Hamlet finally triumphs over his ghost shadow of negative perceptions of the world but in the case of 'Prufrock', he succumbs to his percepts.

Another issue that comes forth is his habit of procrastination generated by his negative self. He says "And indeed there will be time, there will be time to murder and create." Now vital issues like murders and creation are usually not procrastinated. Hamlet has become a juncture of criticism because of its delay in committing a murder. He is very much conscious/ aware of the world around him; yet he is prepared for a hundred 'indecisions'. He has lost all hope. He is even 
conscious of the fact that he is not an adolescent; nor is he a young man. He is past forty or forty at least with a bold spot in the middle of his hair. We all know that handsome is that handsome does. But in his case, his own ludicrous image is superimposed on him by his own self, eventually repressing or rather eliminating all that which may be good in him.

His conscious of the women around him, well familiar with their routine, life style and beauty- 'skirts that trail along the floor'. However, he envisages only the negative response from the women-' that is not it at all, which is not what I meant at all.' He is pretty well aware of being straight forward when he mentions the words 'But as if a magic lantern threw the nerves in patterns on a screen: would it have been worthwhile.' But again we notice that he becomes a victim of 'in-articulation'-his ghostly shadow overrunning whatever good he is left with. When he talks about the mundane routine of tea and cakes and ices, he is even conscious of fasting and praying indicating there by the importance of the later. He is not ignorant at all of the sanctity of religion. There is a talk of 'eternal footman' by him at the mention of which he is 'afraid'. However, we find at every step of the poem that his 'shadow of negatives' falls heavier on whatever good is left in his character. He tries to be an evolved identity but fails!

Now "rolling the universe" in a ball shows both his sides. $\mathrm{He}$ is conscious of the unitary design of the creation but is unsure how his ideas are going to be received as there are two sides to the reception. His familiarity with the Bible is strengthened by his reference to 'Lazarus' but still his preconceived notion of the response brings him to a full stop resulting in complete inertia. Even Lazarus' mention is not clear as there are two Lazarus' mentioned in the Bible; one is the brother of Mary and Martha who is brought to life by Christ, and the other a beggar sitting at the gates of Dives.

In the last stanza, his consciousness again resurfaces wherein he admits 'I grow old........I grow old.' The dots and the spaces show his procrastinating attitude and the void which stands in direct contrast to his wearing 'flannel trousers with bottoms rolled'. Walk on the beach is a very pleasant exercise in the normal course of life. It is only a negative perception to think of the sea bed/floor as a 'grave yard'. In his case, we find that sea which is life giving, pleasant, an ancient highway to connect the globe and the house to aquatic fauna and flora, is nothing but a symbol of death and destruction where mermaids are known for drowning their human lovers.

Thus we see that 'Prufrock' is a perfect tragic figure, with a divided and split self, loss of optimism and faith. Although, through-out the poem, he is conscious of everything; he knows the Bible, like a renaissance man, he is curious to explore the untrodden paths but the dichotomy in his 'self' leads to his failure. He is like Faustus and Hamlet, is full of curiosity to explore but lacks the courage to do so. His is a question of 'to be or not to be', and he chooses 'not to be' as his doppelgänger suggests him. The split self in 'Prufrock', is the philosophical conflict in the maturing mind of 'Prufrock' himself. In fact, it was a learning, maturing, assimilating, formative, constructive, destructive and deconstructive stage in Eliot's life when 'Prufrock' was penned down. The later works like 'Four Quartets' show that he had probably matured to the desired extant. This is further strengthened by the marked shift in depicting the 'split self' of 'Prufrock' towards a synthesis/integration of the 'two' into a comprehensive whole as is evident in the design, structure, thought, message and the philosophy of 'Four Quartets'. It is therefore imperative that 'Prufrock' not only resembles the Elizabethan tragic heroes in his behaviour, but even carves out an exclusive analytical space for himself by getting suppressed under the weight of his 'Doppelgänger' which appears to be so Leviathan in nature that it wrecks 'his' nerves and vocal cords. In fact, it is not a 'Love Song', but a 'Death Song'-a dirge, depicting the 'death in life 'plight of a modern and cosmopolitan human being who-like a renaissance man is always on his toes in pursuit of the unattainable, but is unable to accomplish unlike him. Perhaps what seems more appropriate for a complete understanding of the persona and character of 'Prufrock' is to look at him from the depths of the prism of psycho-analytics, religion and philosophy. It seems probable that advancement in the field of modern psychology can help us to understand Prufrock's behaviour, his style of (in) articulation as well as the growth and development of T. S. Eliot as a poet, critic and philosopher. Hence, behavioural and cognitive approaches are suggested.

\section{REFERENCES}

[1] T. S. Eliot, Notes Towards the Definition of Culture, London: Faber and Faber, 1962, p. 43

[2] L. Gordon, T. S. Eliot: An Imperfect Life, 1998, p. 13.

[3] A. D. Moody, Thomas Stearns Eliot: Poet, Cambridge: Cambridge University Press, 1979, pp. 3-4.

[4] V. Eliot, The Letters of T. S. Eliot Vol. 1: 1898-1922, London: Faber and Faber, 1988, pp. 273-589.

[5] M. Jain, Selected Poems and a Critical Reading of the Selected Poems of T.S. Eliot, Delhi: Oxford University Press, pp. 3-14, 1996.

[6] T. S. Eliot, "The influence of landscape upon the poet," Daedalus, vol. 89 , no. 2, p. 422, Spring 1960.

[7] T. S. Eliot, To Criticize the Critic and Other Writing, London: Faber and Faber, 1965, pp. 45-126.

[8] R. Crawford, The Savage and the City in the Works of T. S. Eliot, Oxford: Clarendon, 1987, pp. 13-15.

[9] I. Babbit, Literature and the American College: Essays in Defense of the Humanities, Boston and New York: Houghton Mifflin, 1908, p. 45.

[10] T. S. Eliot, Selected Essays, London: Faber and Faber, 1969, p. 434.

[11] E. Weber, Action Francaise: Royalism and Reaction in Twentieth-Century France, Stanford University Press, 1962, p. 9.

[12] L. Gordon, Eliot's New Life, Oxford University Press, 1988, p. 341.

[13] T. S. Eliot, After Strange Gods: A Primer of Modern Heresy, New York: Hartcourt, Brace and Company, 1934, pp. 43-44.

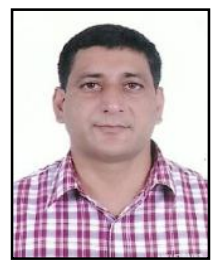

Surender K. Rohilla was born at Gohana, Sonepat district, and was schooled from Sainik School Kunjpura, Haryana, which is functioning under the aegis of Ministry of Defense, Government of India. His higher education had been completed at Kurukshetra University, Kurukshetra and the University of Delhi with a master's degree in philosophy and bachelor's degree in education.

He started teaching at Rishikul Vidyapeeth, Sonepat, Haryana after the completion of his bachelor's in education in 2001. In 2002, he was appointed as a translator with the Ministry of Human Resource Development, Government of India headquartered in New Delhi. The job entailed the translation of government and parliament related documents from Hindi to English and vice versa and implementation of official language rules of government of India. In 2008, he was appointed as an assistant professor in the Department of English, Motilal Nehru College, University of Delhi, South Campus, India, and is continuing at the same position since then. His research interest is in the field of poetry and drama.

Mr. Rohilla is a member of Nehru Memorial Library, Teen Murti Bhawan, New Delhi, and has been the convener of Gandhi Study Circle, Garden Committee and Student's Union apart from being an active member of the International Seminar Committee of the College. He has published poems in a magazine brought out by the English Subject Society of the College of which he is an active member. 